\title{
TECHNOLOGY TRANSFER IN TURKEY *
}

by

Doc. Dr. Necdet Serin **

It will be recalled that the economic approach in the solution of economic development problems maintains that the capital inadequacy, use of primitive or outdated techniques, imbalance in the supply of factors of production result in low levels of output in underdeveloped countries and that, for that reason, the powerty barrier or vicious circle of poverty cannot be removed. According to this approach, the elimination of the above mentioned obstacles would increase the productivity of labor and real income per capita, the society would afford greater savings, the investments would be accelerated, the development would start and gain momentum. To introduce a character of continuity into the process of economic growth depends upon an incessant, factual and significant increases in the per capita incomes or in the average living standars as well as upon similar increases in the labor productivitiy. On the other hand, the labor productivity depends, in its own turn, upon the quantity of capital assets which it employs, the modernity of the techniques used and the technological development rate. Therefore, the economic growth becorres, in a sense, a problem of capital accumulation which englobes the technical and technological development.

Of the above concepts, the technical development denotes the alterations in the production process and in the properties of the equipment, products and organization, as termed with the word

(*) This paper criginally submrtted to the Seminar on The Transfer of Technology to Developing Countrses, Organized by UNIDO and MPM (National Productiviy Center) Ankara, 1973.

(**) Associate professor of economies, Faculty of Political Sciences, Ankara University. 
"discovery» by J. Schumpeter, while the technological development signifies the advancements in the level of knowledge and constitutes, as such, a more abstract event. Stated differently, part of the technological developments are transferred into the implementation field as a technical advancement, depending upon the characteristics related with the economic structure of the country in question, upon the modus of production within the economy and upon the conditions in which the production process is performed. Thence, the technological development is an orientation toward producing new goods, improving the existing ones or reproducing them in a more economic manner or discovering newer production processes.

According to a study (1) made for the purpose of determining the effects of technological developments on the economic growth, the greatest contribution to the increase in incomes in the economic growth of the United States has been played, in connection with the technological developments, by the increases in the efficiancy of physical assets as well as by the improvements in the quality of economic organization, training, knowledge and methods. Another study (2) indicates that 23 percent of the gross national product increases in the United States during the period 1929 . 1969 is attributable to the increase in the training level of the the labor force and 20 percent to the improvements in the technical and business management skills which renders it possible to produce more with the same amount of resource inputs. Still another paper (3) states that 43 percent of the aim of American manufacturing, especially engineering industries in 1962 was to devolop new products through research and development, 40 percent to improve existing products and 13 percent to develop new produc-
tion processes.

Especially since the industrial revolution, the difference between the technological capabilities and the attitudes and implementations of the leaders of business life in developed economies as rather small as compared with that in the developing countries. The same may also be said of the differences between the technological capabilities and the technology levels in production activities. Therefore, the achievement of economic growth in the underdeveloped or developing countries depends, in all probability, upon greater implementation to production activities of the existing. technological knowledge than in the developed economies.

As will be understood from this short introduction, the development or modernization processus is almost always tantamount 
to the abandonment of old methods in favor of newer and more efficient ones, to the development of entirely new products and to the discovery of new ways of life. All these changes have been and may be achieved through the technological change which is now synonymous with the development. For this reason, the acquisition of new technologies and the expansion of new techniques bear a vital importance for all countries concerned, and there exists a source from which may benefit all such countries in order to bring about this change processus: the establishment of a tieup between the organized research activities and development affort in all countries and the absorption of technical and scientific developments marked elsewhere. The first alternative implies the production and the second the transfer of technology.

Though a part of the newer techniques have found application in developing economies, their effects were noticeable only in a certain and limited number of activity branches and they did not produce staggering effects on the socio-economic structures of the countries involved, where the main production activities retained their primitive characters. Thus, until and unless a concerted affort is spent, the impact of technological developments in the developing countries will be relatively insignificant and the technological gap between the developed and developing economies shall continue to grow as the scientific development continues in the former group of countries.

It should be pointed out, however, that the existence of such a wide technological gap provides at the moment considerable opportunities for the developing countries in that it would be possible to draw upon a great wealth of technical and scientific knowledge thoroughly tried in developed countries, via making such alterations thereon as may be necessitated by the needs and conditions prevailing in the developing group of nations. Particularly when we take into aceount the situation of the economies striving for a rapid growth with their limited resources, new vistas shall be opened for the developing countries for attaining higher growth rates through a better use of their available resources and a more rational policy 
whereby technology may be transferred under their own terms and conditions from the developed countries instead of producing them via prohibitively heavy investments in training, research and development in a continuous manner. Thus, while the production of technology constitutes the major stimulant for economic growth in developed countries, those at the initial stages of the development processus will find themselves constrained to fuel their growth efforts by a large - scale technology transfer activity.

The term "technology transfer» is used to denote «the movemen of techno - economic knowledge between the firms, sectors, districts and areas or between two or more economies» and signifies in practice the exchange of technical knowledge between national economies. In other words, «a secondary. innovation, or the implementation of a primary innovation originally discovered or applied by another firm", which may briefly be termed as the propagation of the innovation becomes a technology transfer (4).

The manners in which technology is transferred may be classified as follows (5):

1) License, patent and know - how agreements,

2) Foreign investments and the knowledge imported as foreign capital,

3) Imports of machinery and equipment,

4) Travel, emigration, student and specialist exchanges and other personel relationships,

5) Books, periodicals, abstracts, film, blueprints and other dissemination and exposition means and methods,

6) Technical assistance programmes,

7) Imitations, copying and industrial espionage.

The technology transfer is generally achieved through the imtechnical knowledge in Turkey which aims at modernizingits ecoports of finished production machinery and equipment and of technical knowledge in Turkey which aims at modernizing its economy and especially its manufacturing industries, at accelerating 
the processus of change in the structure of consumption and the socio - economic basis, at improving its growth rate, at causing a structural change in its export trade via benefiting from the import - substituting effects of the technical development and at diversification of its exports whereby the copetitiveness may be increased. The means it used to ensure this transfer are the foreign capital, joint - purpose enterprises, trade of production goods, license angeements, purchases of special services, exchange of technical knowledge and technical assistance (6).

It is to be mentioned here that a distinct separation of the technology transfer channels are almost impossible to disentangle from each other. Even if a separation is made, several difficulties of theoretical, practical and statistical nature on which we will not dwell here shall arise. For this reason, the problems of international transfers of technology are generally examined along two major channels, which consist of foreign capital investments on which adequate and reliable statistical data ara available, and the purchase of such intangible rights as the licenses, patents and know - how. It is not to be denied that technology can be transferred also via the imports of machinery; but difficulties arise on determining whether the technology is actually imported through such imporis and an establishing the extent and value of the transfer involved in this manner, since the figures available on said imports do not provide data on technology transfers concurrent therewith. Despite the fact that technology may be, and is physically transferred in this fashion, that realized through the purchases of such intangible rights as licenses, patents and know - how is somewhat different from the imports of machinery and equipment or the foreign capital investments in that former renders it possible to acquire also the so - called «non - included» technology. Furthermore, the agreements on the purchase of intangible rights are generally concluded in such a manner as to complement the foreign investment contracts. For these and other reasons, the measurements of technology transfer are generally limited by the data available on the documents concerning the license, patent and know - how agreements. 


\section{TABLE 1}

FOREIGN CAPIAL INVESTMENTS

UNDER. LAW \$.6224

Turkish Lira

Value of

Foreign

Capital

Physically

Years Imported

1950

1951

1952

1953

1954

1955

1956

1957

1958

1959

1960

1961

1962

1963

1964

1965

1966

1967

1968

1969

1970

1971

1972 (a) 129.125 .214

Total 1.052.186.815

3.410 .000
21.654 .000
3.842 .000
45.874 .000
20.641 .000
9.005 .000
2.509 .000
3.032 .000
5.581 .000

11.372 .285

31.725 .000

56.362 .000

78.902 .000

61.693 .250

82.358 .888

69.580 .166

67.749 .842

92.356 .699

69.366 .851

102.917 .044
Turkish

Lira

Payments to

Abroad as

Profit

90.558 .561

.052.186.815

54.980 .823

62.692 .305

68.226 .573

63.454 .374

74.935 .453
Disboursements to

Abroad for Licenses

Royalties

and

Know - how

TL

$\$$

3.572

11.349

35.315

44.741

149.625

256.616

98.336

168.790

122.676

149.135

1.342 .216

194.809

1.753 .278

442.134

3.979 .208

2.107.170

234.130

9.234.914

2.750 .670

13.928 .795

9.511 .980

5.685 .792

18.361 .535

1.026 .023

305.609

23.516.331

97.083.519
1.547 .643

105,689

382.882

1.311 .538

1.679 .738

8.270 .371

(a) At the end of Angust

(b) $\$ 1=$ TL. $2.80(1950-1957) ; \$ 1=$ TL. $9.00(1958-1969) ; \$=$ TL. 14.85 (1970); $\$ 1=$ TL. $14.00(1971-1972)$

SORUCE : Union of the Turkish chamber of commerce, Industry and stock Mar-kets, Economic Report 1973, Ankara 1973. (For the columas 1, 2 and 3) 
Table 1 given above compiled from the Economic Report for 1973 published by the Union of Chambers of Turkey, indicates the amounts of foreign capital physically imported into Turkey, the disboursements made to abroad for profits and those against patent, royalty and know-how purchases. The 1972 figures cover the period from 1 January to 31 August 1972, and the study antitled "Türkiye'de Yabancı Sermaye Sorunu» (Problem of Foreign Capital in Turkey) of B. Tuncer from the Political Sciences Faculty was used for the Turksh Lira values.

According to this table these payments which were a mere TL 10.000 in 1953 have shown a general trend of increase, attained TL 18.361.535 in 1971 and TL 23.516.331 at the and of August 1972. The transfers abroad between primo 1953 and and of August 1972 are TL 552.178.125 as profits and TL 97.083 .519 as the countervalue of intangible rights. In other words, the latter paid to purchase such intangible rights represents the monetary value of the technology transferred by Turkey during the period under examination.

One point which is open to discussion here is whether the values shown for the intangible rights actually correspond to the amounts transferred abroad as indicated on the table. We are inclined to believe that the countervalues due to be transferred are somewhat higher then the amounts transferred, and that the transfer operations were delayed for a variety of reasons which may be (a) the partial or total incomplation of the transfer formalities, (b) the refusals of transfer permits during the years marked with balance of payment difficulties and (c) the use of such transferable funds by the firms concerned for financing new investments. It is believed that the last probability is the strongest of the rest of the causes. If, during the period 1973-1974, this country proceeds with the complete liquidation of such hitherto-abeyed payments by using its foreign currency holdings which have now attained satisfactory levels, it will be possible to determine exactly the monetary value of the technology transfers to Turkey.

If, on the other hand, the amounts shown on the table represent the exact values of such imported intangible rights as patents, licenses and know-how, it should be inferred that the amounts indicated as the price of technologies imported into 
Turkey from early 1950 until the end of August 1972 are no more then 97 million Turkish Liras, or 8.270.371 US dollars. An OECD source (7) indicates that the total foreign disboursoments made by Turkey during the period $1960-1970$ as the monetary value of

\section{TABLE 2}

TOTAL EXTERNAL PAYMENTS OF TURKEY

FOR LICENSES, KNOW - HOW AND MANAGEMENT FEES

BY MANUFACTURING INDUSTRIES

\begin{tabular}{|c|c|c|c|}
\hline Yeor & Quantity & & $\begin{array}{l}n \text { million } \\
\text { Quantity }\end{array}$ \\
\hline-- & -- & -- & --1 \\
\hline 1960 & 0.09 & 1966 & 1.88 \\
\hline 1961 & 0.11 & 1967 & 0.30 \\
\hline 1962 & 0.08 & 1968 & 1.54 \\
\hline 1963 & 0.55 & 1969 & 1.05 \\
\hline 1964 & 0.73 & 1970 & 0.58 \\
\hline 1965 & 1.55 & & \\
\hline
\end{tabular}

transferred lisenses, patents and know-how is 8.460 .000 US dollars. We had determined, based upon the Turkish sources, in Table 1 that the value of disboursements made abroad under different exchange values within the same period of time was TL 52.917.521 or US $\$ 4.675 .541$. There appears therefore a considerable difference between these two sets of figures. If we assume that a difference of the same size exists also for the period 1950-1972 and that the values of intangible rights amounts to US $\$ 16.540 .742$, it would not be possible to claim that this represents a considerable technology import insofar as a country which cannot be said to be a technology producer and which is following an industrialization processus based upon technology imports is concerned.

One of the two countries which has complete and fully reliable data on technology imports and exports, Japan which is also a mejor technology producer has imported technology valued at US $\$ 1.040 .899 .100$ during the period 1950-1965. Within the same period, Turkey's technology imports are a more TL 14.093 .502 or US $\$ 1.911 .228$ (8). Thence, a huge difference in terms of monetary value of the technologies transferred exists between these two countries. In fact, one of the foremo st reasons behind the difference between the development levels, economic structure and strength 
of these two countries in this colossal gap between their technological levels.

TABLE 3

RATIO OF LICENSE, PATENT AND KNOW-HOW

PAYMENTS TO INVESTMENTS

Ratio of Lincense, Patent, Know-how etc.

Payments to

Gross Investment Values

Engineering, Transportation and Communication Industry Investment Values

Eigineering Industry Investment Values OnI

\begin{tabular}{crr} 
Japan & \multicolumn{3}{c}{ (in perceatages)) } \\
1965 & \multicolumn{2}{c}{ Turkey } \\
1865 & 1971 \\
0.6 & 0.018 & 0.056 \\
& & \\
1.6 & 0.06 & 0.1 \\
2.1 & 0.1 & 0.2
\end{tabular}

Sources: UN, «Statistical Yearbook»; IMF, «International Financial Statistics*; OLDHAM, FREEMAN and TURKCAN, "Trends and Problems in World Trade and Development, New Delhi; DPT (STATE PLANNING ORGANISATION), Five-year development plans and annual programmes.

If we take the issue from the standpoint of investment volumes and ratios to technology transfers, we see that the payments made by Japon in 1965 for licenses, pantents and know-how in function to gross investments, engineering, transportation and communication investments and to engineering investments only are immaasurable larger than those of Turkey (Table 3).

If we examine the situation of Turkish industry from the standpoint of dependency upon technology importations, in accordance with the figures furnished by the United Nations (Table 4), we will find that the "ratio of dependency upon foreign technology" of Turkey is still negligible, as compared with the other two countries examined.

TABLE 4

RATIO OF TECHNOLOGICAL DEPENDENCY (RATIO OF TECHNOLOGY PAYMENTS TO VALUE ADDED OF ENGINEERING INDUSTRIES)

\begin{tabular}{llllll} 
& & & \multicolumn{3}{c}{ (in percentages) } \\
Country & 1963 & 1964 & 1965 & 1966 & 1967 \\
Spain & 1.00 & 1.10 & 1.40 & 1.50 & 1.60 \\
Greese & 0.20 & 0.20 & 0.20 & 0.30 & 0.30 \\
Turkey & 0.04 & 0.08 & 0.09 & 0.10 & 0.06
\end{tabular}

Source : UNITED NATIONS, «Some Aspects of Manufacturing Development in Southern Europe : Production, Trade and Transfer of Technology,, in: Economic Bulletin for Europe, Vol. 23, No. 2, p. 73 . 
According to the computations made by E. Turkcan (9), transfers of intangible right totalling 17 million Turkish Liras were made in rubber industry and 14 millions in pharmacauticals during the period 1950-1966. This may be explained by the fact that the profit rates are high in these two industries. In the electrical machinery sector, these transfers are 8.5 million Turkish Liras within the same period. According to the same source, the first rank in the transfers for intangible rights in ratio to transfers of total foreign capital investment profits belongs to pharmaceuticals with $338 \%$, second rank to transportation vehicles with $103 \%$, third rank to rubber with $76 \%$ and fourth rank to electrical machinery and appliances with $52 \%$.

In the light of the explanations given on the transfer or technology in Turkey, the following conclusions may be drawn :

1) If we disregard the technology transfers which are impossible to measure and which are made thrcuigh the machinery, equipment and direct foreign capital investments, the monetary value of those made via purchases of license, patent, know-how, etc is negligibly small. It must also be indicated here that a significant part of such purchases are not technology transfers in the true context of the word, but rather the payments made to obtain the authorization to use a certain trademark. Here, the technology transfer would in all probability not be in question since a product would be produced solely under a forcign tradename. The possibility should not be precluded, however, of an eventual technology transfer together with the authorization to use the relevant trademark.

2) Even if we assume that the technology transfer involves something more than the purchase of a given trademark, the negligibility insofar as the amount is concerned may be explained by the fact that (a) the technology transferred is outmoded and consequently cheap or, stated differently, insignificant amounts of technology are being transferred in traditional industry subsectors where varying degrees of experience are accrued, (b) Turkey has not attained an industrialization level necessitaing the use of advanced and hitherto unimported technologies. As indicated in the Third Five-year Development Plan (10), Turkey has not attained in the last decade a major development in favor of the industry of investment goods -which depends largely upon technology 'transfers- within the basic engineering industry subsectors, and its industry is still oriented toward the production 
of consumer goods whose contribution to the development may at best be termed as rather doubtful.

3) The technology transfers appear to be less than they actually are, due to the fact that the disboursements necessitated by the purchase of intangible rights concerning the technology imported after 1970 in petrochemicals, automotive and electirical industries as a result of the delays incurred in their partial or total transfer abroad. Even if we assume that the technology transfers are actually small in scope, necessity will arise in the near future for large-scale transfers and consequently significant disboursements when the more advanced techniques begin to be implemented and when, especially, the aircraft industry is founded. In other words, the next stage in the industrialization of Turkey will increase the transformation momentum in the Turkish industry and render it imperative for its economy to follow a more intense modernization processus.

4) The industrialization processus of the near future will require the production of technology together with greater imports of technology.

5) The new technologies to be put onstream in the production acricities should be examined as to whether they encompass one or more of the following properties (10): a) greater capacity, b) automation, c) direct methods (such as the production in a single operation of iron foundry goods from blast furnace to final product), d) new products, e) miniaturization and weight reduction, and $f$ ) better quality and higher performance in the products.

6) Both the realization of technology production and the implementation of such technologies in form of new and advanced techniques compatible with the local conditions rather than a utilization in statu presentam will require considerable research and development investments. For this reason, it is imperative that the number of researchers who number around 6,000 in Turkey at the moment and the research and development expenditures which are in the neighborhood of $0.4 \%$ of the gross national product today (this percentage is in the vicinity of 4 in developed economies) should be significantly increased and that the educational efforts should be oriented in a direction truly compatible with the abjectives of the economic development. In other words, there exists a requirement for developing the manpower resources in a rapid and growth-conscious manner commensurate with the research and development needs to better support the 
economic development aims, failing which the production and transfer of technology as well as its adaptation to the conditions prevailing in the country will not be achieved with the result that the growth rate will decelerate instead of accelerating, even if it were possible to make sufficient investments for a faster and more balanced development, since the increases in the manpower resources will not be able to keep abreast with the physical capital accumulation. Therefore, as Turkcan puts it (12), it is of vital importance that the science and technology should be introduced in a most concentrated and efficient manner into the development processus as separate parameters together with such other conventional production factors as the capital, labor and natural resources, that a "scientific research sector" should be created, that this sector is speedily and efficiently supported in order to enable it to determine a strategy whereby the economy can be integrated, that the development plans should consequently be rendered more effective, that the Turkish development proces should be given the characters of rapidity and balancedness and the place of Turkey within the European Economic Community should be made stronger from the economic viewpoint.

7) All concerned organization, with particular emphasis on the State Planning Organization, the Ministry of Industry and Technology and the Turkish Scientific and Technical Research Council, should conduct detailed studies on the technology production and transfer and should initiate such studies without delay under a philosophy which considers that the science and technology policy as inseparable from that of economics. In other words, the degres of success to be attained in this domain will be dependent upon the cooperation between economists and engineers and between the economic planners and science planners. The absence or utter inadequacy of such a cooperation in Turkey consititues one of the foremost factors which hamstrings our economic and social development. 
(1) Abramovitz, M., "Resources and Output Trend in the United States Since 1870", National Bureau of Economic Research, Occasional Paper No. 52, New York 1956.

(2) Denison, E. F., "The Sources of Economic Growth in the United States", Committee for Economic Development, New York 1962, pp. 124-129.

(3) Mansfield, E., The Economies of Technological Change, W. W. Norton and Co., lnc., New York 1968, p. 11.

(4) Türkcan, E., İktisad' Kalkınmada Bilim ve Teknoloji, Faculty of Political Sciences, Ankara 1972, a mimeographed doctorate thesis.

(5) Oldham, Freeman and Türkcan, "Trends and Problems in World Trade and Development" in U. N. Conference on Trade and Developmént, p. 8, Türkcan, ibid, p. 135.

(6) D.P.T., (State Planning Org.), Uçüncï Beş Yıllık Kalkınma Plânı, Ankara 1973 , p. 682.

(7) OECD., The Transfer of Technology, Paris 1971, p. 46.

(8) Oldham et. al., Op cit., p. 21.

(9) Türkcan, E., Measurement of Transfer of Technology in Turkey., Turkish Scientific and Technical Research Council, Ankara 1967, (Stencilled) pp. 14-22.

(10) D.P.T., op. cit., p. 692.

(11) Oldham, C. H., "Characteristics of the Process of Transfer of Techno_ logy", in Second Meeting of CIECC February 1971, Lima, p. 3.

(12) Türkcan, op. cit., p. 209. 